\title{
一氧化碳添加对甲烷/空气贫燃预混火焰的影响
}

\author{
陈文婷蒋 勇 ${ }^{*}$ 邱榕 \\ (中国科学技术大学火灾科学国家重点实验室, 合肥 230026)
}

\begin{abstract}
摘要：通过对贫燃条件下(燃料与空气化学计量比 $\varphi=0.60-0.80$ )的甲烷/一氧化碳/空气火焰结构进行数值模拟, 研究燃料中一氧化碳添加量对层流燃烧速度、氮氧化合物的排放以及熄火拉伸率的影响. 随着燃料中一氧化碳 添加量的不断增加, 层流燃烧速度有所下降, 这与燃料中加人氢气产生的现象有所不同. 为了解释这一现象, 本 文深人探讨了层流燃烧速度与 $\mathrm{H}+\mathrm{OH}$ 浓度峰值之间的关系, 结果表明, 一氧化碳的增加导致 $\mathrm{H}+\mathrm{OH}$ 浓度峰值呈 线性下降, 与层流燃烧速度下降趋势完全一致. 随着一氧化碳的增加, 氮氧化合物排放量有所下降. 探讨了 NO 的生成机理, 且由敏感性分析得到生成 NO 的重要反应, 分析当一氧化碳量增大时, NO 的浓度以及重要反应的 $\mathrm{NO}$ 生成率均下降. 此外, 利用数值模拟求解径向拉伸率, 深人分析燃料中添加一氧化碳时拉伸率对贫燃火焰稳 定性的影响. 由计算结果得到熄火拉伸率, 发现燃料中一氧化碳的添加在一定程度上能够增强火焰的稳定性.
\end{abstract}

关键词：一氧化碳添加；层流燃烧速度；氮氧化合物排放；熄火拉伸率

中图分类号: 0643

\section{Effects of CO Addition on the Lean Premixed $\mathrm{CH}_{4} /$ Air Flame}

\author{
CHEN Wen-Ting JIANG Yong* $\quad$ QIU Rong \\ (State Key Laboratory of Fire Science, University of Science and Technology of China, Hefei 230026, P. R. China)
}

\begin{abstract}
A numerical study was carried out to determine the effects of $\mathrm{CO}$ addition on the laminar burning velocity, $\mathrm{NO}_{x}$ emission, and extinction strain rate in a premixed $\mathrm{CH}_{4} / \mathrm{CO} /$ air flame under the lean condition (equivalence ratio of fuel to air $\varphi=0.60-0.80$ ). When more $\mathrm{CO}$ was added to the fuel, the laminar burning velocity decreased, which is different from that observed for $\mathrm{H}_{2}$ addition. To explain this, we studied the strong correlation between laminar burning velocity and $\mathrm{H}+\mathrm{OH}$ peak concentrations. Results showed that the $\mathrm{H}+\mathrm{OH}$ peak concentrations decreased linearly with an increase in $\mathrm{CO}$ content. This tendency is in good agreement with that of the laminar burning velocity. For $\mathrm{NO}_{x}$, we observed that increments in $\mathrm{CO}$ addition led to a remarkable reduction in the $\mathrm{NO}_{x}$ emission. In addition, we investigated the NO formation mechanism and determined the relevant reactions for NO production using a sensitive analysis. The NO concentrations decreased significantly with enrichment by $\mathrm{CO}$ and the NO production rate also clearly decreased. We calculated the radial strain rate $S_{\text {rad }}$ and discussed the influence of strain rate on lean flame stability with regards to the addition of different $\mathrm{CO}$ mole fractions to the fuel. The extinction strain rates indicated that the lean flammability limits were extended by $\mathrm{CO}$ addition in some way.
\end{abstract}

Key Words: $\quad \mathrm{CO}$ addition; Laminar burning velocity; $\mathrm{NO}_{x}$ emission; Extinction strain rate

At present, due to energy crisis as well as global environmental threats, lean combustion technology has received great attention in the combustion and other related fields, so lean combus- tion has become a popular method to meet increasingly stringent emissions requirements. Some researchers ${ }^{[1]}$ have pointed that lean combustion can greatly reduce the fuel consumption and emis-

Received: January 7, 2010; Revised: March 17, 2010; Published on Web: April 27, 2010.

*Corresponding author. Email: yjjiang@ustc.edu.cn; Fax: +86-551-3601669.

The project was supported by the National Natural Science Foundation of China (50876097) and Program for New Century Excellent Talents in University of China (NCET-06-0546).

国家自然科学基金(50876097)和教育部新世纪优秀人才支持计划(NCET-06-0546)资助

C Editorial office of Acta Physico-Chimica Sinica 
sions of greenhouse gases and pollutants, including $\mathrm{NO}_{x}$, soot ${ }^{[2]}$, and other particle matter, which was mainly the result of the low flame temperatures encountered in the lean conditions ${ }^{[3-5]}$.

The lean combustion has its special prospects, but has some disadvantages. The most serious one is that at low equivalence ratio, the combustion stability will be affected and the processes of stretching and heat loss may cause extinction ${ }^{[6]}$. To solve this problem, the traditional approach is to adopt fuel enrichment and increase the concentration of the fuel. Though this strategy can enhance the overall burning intensity and the flame stability, but the flame temperatures and the $\mathrm{NO}_{x}$ emissions will be increased. Another method is to add a small amount of other fuels, which can solve the stability problem, while, the $\mathrm{NO}_{x}$ emissions can receive substantial reduction. Hereto, some researchers suggest adding reformate gas to ensure the flame stability, which can diminish the quenching distance and extend the flame limits, as well as reduce $\mathrm{NO}_{x}$ formation. It is well known that $\mathrm{H}_{2}$ is an important component of reformate gas, so hydrogen addition has attracted many scholars' research. And the previous studies have proved that hydrogen addition can widen the lean burn operation and reduce unburned hydrocarbon and carbon dioxide emissions ${ }^{[7-8]}$. This method was discussed more by $\mathrm{Yu}$ et al..$^{[1]}$, and they measured the fundamental laminar flame speed of $\mathrm{CH}_{4} /$ air flame with $\mathrm{H}_{2}$ addition by using the counter flow configuration. Rørtveit et al. ${ }^{[9]}$ studied the lean premixed flame utilizing four kinds of burner experimentally and their results revealed that the flame stability with $\mathrm{H}_{2}$ addition and the $\mathrm{NO}_{x}$, $\mathrm{CO}$ emissions depended largely on the type of burner and the excess air ratio.

Even though this is an attractive proposition, some specialists, such as Ren et al. ${ }^{[5]}$ pointed that we must realize that it is a challenge to make a large number of $\mathrm{H}_{2}$ into use because it is expensive to produce. In comparison, the production and storage technology of $\mathrm{CO}$ has been quite mature. However, the effect of the addition of various additives on the $\mathrm{CH}_{4} /$ air flame has been investigated, such as $\mathrm{H}_{2}$, reformate gas ${ }^{[10-13]}$, astonishingly there is very few information available in the related literature about the influence of $\mathrm{CO}$ addition, especially considering the condition of lean burning. As a kind of important component of reformate gas, it is necessary to study the combustion characteristics of $\mathrm{CO}$. Hence, in this case, we investigate the characteristics of the $\mathrm{CH}_{4} /$ air flame with different $\mathrm{CO}$ additions under the condition of lean burning (equivalence ratio, $\varphi=0.60-0.80$ ). It has been thought that the laminar burning velocity is an important parameter of a combustible mixture as it contains fundamental information regarding reactivity, diffusivity, and exothermicity ${ }^{[14]}$, on which the changes of flame structure and dynamics are found to depend when fuel composition is varying. The control of $\mathrm{NO}_{x}$ emissions has become an essential factor in the design of modern combustion systems ${ }^{[5]}$ and the extinction strain rate is the main basis of the flame stability judgment. Therefore, we focus on these three most concerning problems to analyze specific changes with different $\mathrm{CO}$ mole fractions in the fuel.

\section{Modeling details}

\subsection{Chemical kinetic model}

In this paper, we employ the kinetic model of GRI Mech 3.0 $0^{[16]}$, which consists of 325 elementary chemical reactions and 53 species, including $\mathrm{NO}_{x}$ kinetics. This kinetic model has been tested and validated extensively for $\mathrm{CH}_{4}$ and other natural gases combustion over a wide range of pressure and temperature conditions. Guo et al. ${ }^{[17]}$ has investigated the extinction strain rate and the $\mathrm{NO}_{x}$ emissions of the premixed $\mathrm{CH}_{4} / \mathrm{H}_{2} /$ air flame by employing GRI Mech 3.0, whose object has much consistency with ours.

\subsection{Computational specification}

According to the object of this study, two different flame models are employed. One is freely propagation flame to get the laminar burning velocities and some parameters to analyze the characteristics of $\mathrm{NO}_{x}$ emissions which is calculated using the PREMIX software ${ }^{[18]}$ and the other is opposed-jet, symmetric, twin-flame to investigate the extinction strain rate by adopting the OPPDIF software ${ }^{[19]}$. In the previous work, these two models were used mostly to compare experimentally observed trends with those predicted by the calculations. Moreover, the two softwares, which were applied mostly by scientific researches and validated in practical engineering fields ${ }^{[20-21]}$, were both developed by Sandia National Laboratories. In the $\mathrm{NO}_{x}$ section, the NO related important reactions was obtained by utilizing the SENKIN package ${ }^{[22]}$ of CHEMKIN II ${ }^{[23]}$ to analyze the influence of CO addition thoroughly.

In addition, in this study, there are some parameters as follows: $\mathrm{CH}_{4} / \mathrm{CO} /$ air flames with global equivalent ratios $\varphi=0.60$ 0.80 , and $\mathrm{CO}$ mole fraction in $\mathrm{CO} / \mathrm{CH}_{4}$ mixture $\alpha=0.0-0.9$, where $\varphi, \alpha$ are defined as,

$$
\begin{aligned}
& \varphi=\frac{\left[\left(\sum_{i} X_{\text {fuel }_{i}}\right) / X_{\mathrm{O}_{2}}\right]_{\text {actual }}}{\left[\left(\sum_{i} X_{\text {fule }_{i}}\right) / X_{\mathrm{O}_{2}}\right]_{\text {stoich }}} \\
& \alpha=X_{\mathrm{CO}}\left(X_{\mathrm{CO}}+X_{\mathrm{CH}_{4}}\right)
\end{aligned}
$$

where $X_{i}$ is the mole fraction of species $i$ in the fuel.

\section{Results and discussion}

As mentioned above, we investigate the effect of $\mathrm{CO}$ fraction on the $\mathrm{CH}_{4}$ /air flames in terms of the laminar burning speed, the extinction strain rate, and the $\mathrm{NO}_{x}$ formation under the circumstance of the lean burning $(\varphi=0.60-0.80)$.

\subsection{Laminar burning velocity}

The calculations of the unstretched laminar burning velocities are performed with an unburned mixture under the normal atmospheric pressure. The temperature and the mass flow rate are set as $400 \mathrm{~K}, 0.04 \mathrm{~g} \cdot \mathrm{cm}^{-2} \cdot \mathrm{s}^{-1}$, respectively. The adaptive mesh parameters are GRAD $=0.2$ and GURV $=0.6$. The absolute and the relative error criteria are $\mathrm{ATOL}=1 \times 10^{-9}$ and $\mathrm{RTOL}=1 \times 10^{-4}$. Fig. 1 shows the laminar burning velocity under various $\mathrm{CO}$ ad- 


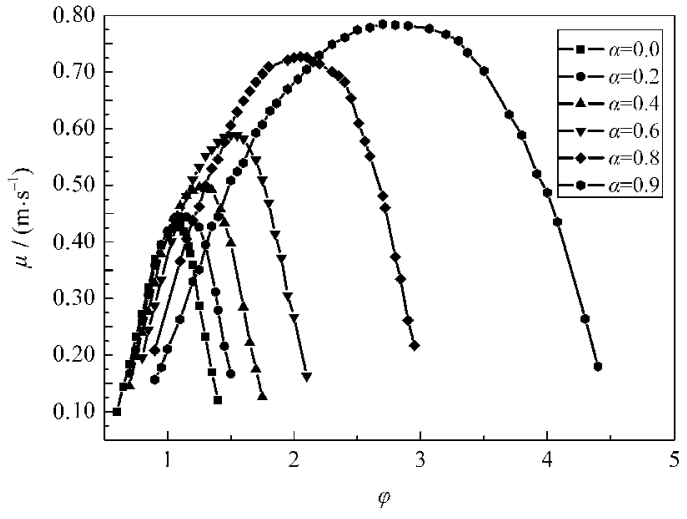

Fig.1 Laminar burning velocity $(\mu)$ as a function of equivalence ratio with various $\mathrm{CO}$ additions in $\mathrm{CH}_{4}$ /air flames

dition, and equivalence ratios. We can note that (1) the laminar burning velocities reach the maximum at the rich side of stoichiometry; (2) when equivalence ratios are higher than 1 , the velocity increases obviously with the increase of $\mathrm{CO}$ mole fraction in the fuel mixture. These results are in accord with the researches by $\mathrm{Wu}$ et al. ${ }^{[2]}$. However, their studies have been restricted to the velocity changing trends at the overall equivalence ratios and the main positions of the maximum velocity, without aiming at the lean burning condition.

So we calculate the laminar velocities at $\varphi=0.65,0.70,0.75$ with the changes of $\mathrm{CO}$ concentration in the fuel. Fig. 2 shows that both the decreases of the equivalence ratio and the increases of the $\mathrm{CO}$ mole fraction lead to the reduction of the velocities. The result of Fig.1 is similar to the case of hydrogen addition to the fuel ${ }^{[8]}$, while in Fig.2, we can observe that the result is obviously different from the hydrogen case. Halter et al. ${ }^{[24]}$ studied the influence of hydrogen fraction on the laminar burning velocity of $\mathrm{CH}_{4} / \mathrm{H}_{2}$ flame and the results showed that the laminar burning velocity increased as the increase of hydrogen fraction in the fuel mixture. Hu et al. ${ }^{[25]}$ investigated the effects of the radical mole fractions of $\mathrm{OH}, \mathrm{H}$ on the burning velocity and they proposed that there was a strong correlation between burning velocity and maximum radial mole fractions of $\mathrm{OH}+\mathrm{H}$ radicals in the reaction zone of the premixed $\mathrm{CH}_{4} /$ air flames. They pointed

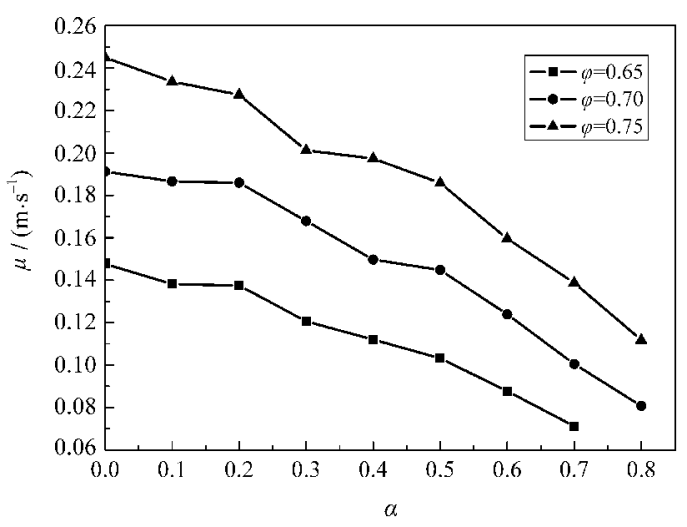

Fig.2 Laminar burning velocity as a function of $\mathrm{CO}$ addition in $\mathrm{CH}_{4} /$ air flames

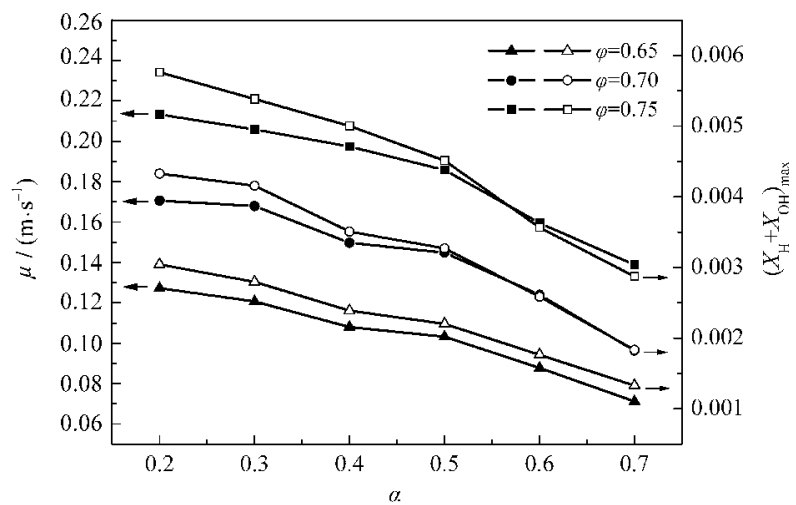

Fig.3 Laminar burning velocity and maximum $\mathrm{OH}+\mathrm{H}$ mole fraction with various $C O$ additions at $\varphi=0.65,0.70,0.75$

that with the increase of maximum concentration of $\mathrm{OH}+\mathrm{H}$, the burning velocity increased and also gave the detailed formulation, the burning velocity $\mu=0.07929+\left(X_{\mathrm{H}}+X_{\mathrm{OH}}\right)_{\max }$, i.e., $\mu$ changed linearly with $\left(X_{\mathrm{H}}+X_{\mathrm{OH}}\right)_{\max }$. Fig.3 shows the laminar burning velocity and the maximum mole fraction of $\mathrm{OH}+\mathrm{H}$ at three different lean equivalence ratios. We can conclude that (1) at three ratios, the change trends of velocity are consistent with the peak mole fraction, that is, linear relationship exists between them, which is verified by the contrast between the simulation results and the fitting results in Fig.4. And the linear relationships can be expressed by the following formulas, respectively,

$$
\begin{aligned}
& \mu_{0.65}=0.00151+0.99779\left(X_{\mathrm{H}}+X_{\mathrm{OH}}\right)_{\max } \\
& \mu_{0.70}=0.00215+0.99777\left(X_{\mathrm{H}}+X_{\mathrm{OH}}\right)_{\text {max }} \\
& \mu_{0.75}=0.00271+0.99628\left(X_{\mathrm{H}}+X_{\mathrm{OH}}\right)_{\text {max }}
\end{aligned}
$$

(2) as more amount $\mathrm{CO}$ mole fraction in the fuel, the burning velocity and the maximum $\mathrm{OH}+\mathrm{H}$ mole fraction decrease remarkably. Actually, the increases of $\mathrm{CO}$ addition cause the peak concentration of $\mathrm{OH}$ and $\mathrm{H}$ radicals to decrease at different lean equivalence ratios which are showed in the Fig.5.

\section{$2.2 \mathrm{NO}_{x}$ emissions}

As one of the main sources of the air pollution, $\mathrm{NO}_{x}$ emissions not only have a detrimental effect on human health, but also contribute significantly to the global environmental pollution, which has caused lots of concerning in the combustion and envi-

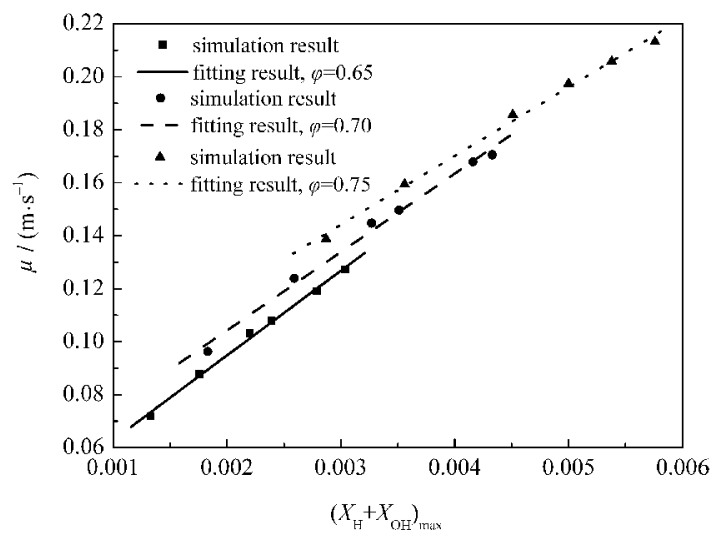

Fig.4 Laminar burning velocity at various peak $\mathrm{H}+\mathrm{OH}$ mole fractions 


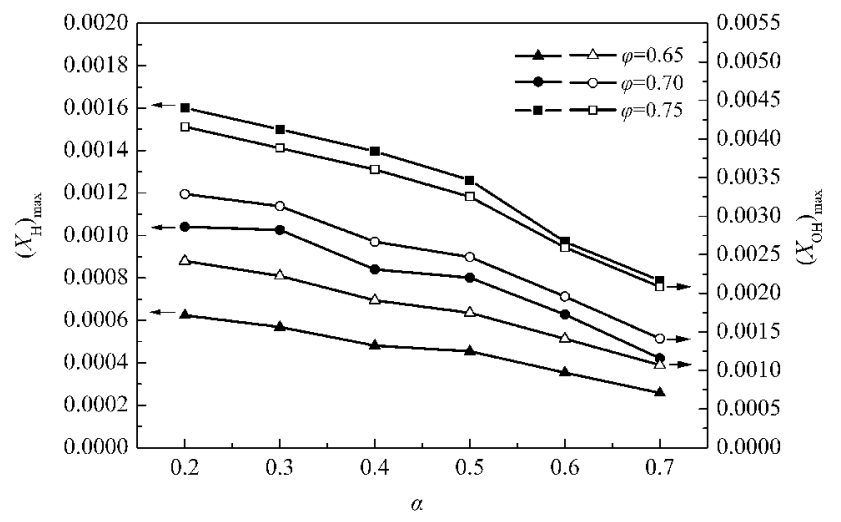

Fig.5 Maximum $\mathrm{H}$ and $\mathrm{OH}$ mole fractions at different $\mathrm{CO}$ mole fractions in the fuel

ronment fields. Plenty of studies have focused on the effect of adding $\mathrm{H}_{2}, \mathrm{CO}_{2}, \mathrm{H}_{2} \mathrm{O}$ to natural gas on $\mathrm{NO}_{x}$ production ${ }^{[26]}$. And in this section, we study the effects on the $\mathrm{NO}_{x}$ emissions index by adding $\mathrm{CO}$, on the other hand, some questions related to the formation mechanisms are discussed. Fig.6 shows the distribution of the typical $\mathrm{NO}_{x}\left(\mathrm{NO}, \mathrm{NO}_{2}, \mathrm{~N}_{2} \mathrm{O}\right)$, and obvious differences are observed between $\mathrm{NO}$ and $\mathrm{N}_{2} \mathrm{O}$ formation. The NO formation mostly occurs in the high temperature region, while the $\mathrm{N}_{2} \mathrm{O}$ is mainly generated in the low temperature zone, while $\mathrm{N}_{2} \mathrm{O}$ is consumed in the high temperature region. These mainly depend on the formation mechanisms of $\mathrm{NO}$ and $\mathrm{N}_{2} \mathrm{O}$. The mole fraction of $\mathrm{NO}$, which accounts for $90 \%$ in the $\mathrm{NO}_{x}$, is much higher than $\mathrm{N}_{2} \mathrm{O}$ and $\mathrm{NO}_{2}$, so in the following studies we will take $\mathrm{NO}$ for the main research object.

\subsubsection{Flame temperature}

It has been known that the formation of $\mathrm{NO}_{x}$ has been extremely influenced by the flame temperature. So many researchers, such as Tuzson ${ }^{[27]}$ and Maughan et al. ${ }^{[28]}$, have proposed to get low $\mathrm{NO}_{x}$ emissions by bringing down the flame temperature. Because the thermal mechanism plays an important role in high temperature, the emissions are strongly depending on the high temperature, moreover in the Fig. 7 we can observe that as the raise of the flame temperature, the $\mathrm{NO}_{x}$ concentration will increase. So in a large extent, we can conclude that high temperature indicates the high $\mathrm{NO}_{x}$ concentration. Fig.8 gives

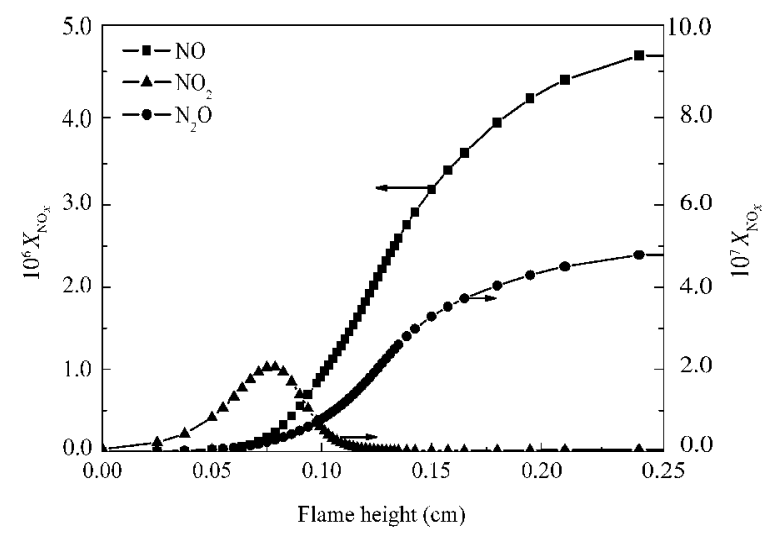

Fig.6 Profiles of mole fractions of $\mathrm{NO}, \mathrm{NO}_{2}$, and $\mathrm{N}_{2} \mathrm{O}$ in the premixed $\mathrm{CH}_{4} /$ air flame

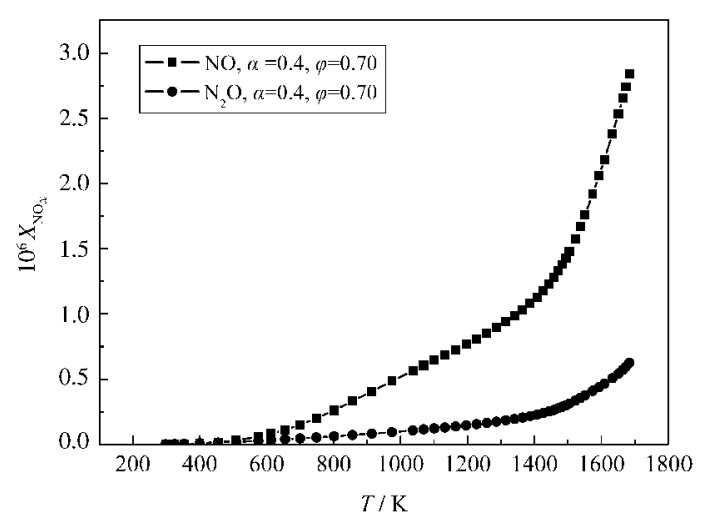

Fig.7 $\mathrm{NO}$ and $\mathrm{N}_{2} \mathrm{O}$ mole fractions at various temperatures

the profiles of temperature of $\mathrm{CH}_{4} /$ air flame with different $\mathrm{CO}$ additions at $\varphi=0.70$. As $\mathrm{CO}$ addition increases, there is a small decrease in the temperature. According to the theory aforementioned, this change indicates that $\mathrm{NO}_{x}$ emissions would achieve significantly reduc-tion.

\subsubsection{NO concentrations}

In order to get a better investigation about $\mathrm{NO}_{x}$ emissions after adding $\mathrm{CO}$, we calculate NO mole fraction at $\varphi=0.70,0.75,0.80$ with $\mathrm{CO}$ addition $\alpha=0.1,0.2,0.4,0.6,0.8$, as seen in Fig.9. It can be seen that at three different ratios, $\mathrm{CO}$ addition has a positive effect on $\mathrm{NO}$ emission reduction, and more $\mathrm{CO}$ concentration leads to lower NO mole fraction. Especially at $\varphi=0.70$, 0.75 , the mole fractions reduce almost $65 \%$, while at $\varphi=0.80$, the mole fraction leaves over $40 \%$ of the original. In general, the $\mathrm{NO}$ emission situation gets a large scale of improvement. We do not calculate $\mathrm{N}_{2} \mathrm{O}, \mathrm{NO}_{2}$, but due to the mole fraction of $\mathrm{NO}$ accounting for about $90 \%$ in $\mathrm{NO}_{x}$, so we can deduce that the total $\mathrm{NO}_{x}$ emissions get a remarkable reduction.

\subsubsection{Problems related to $\mathrm{NO}_{x}$ reaction mechanism}

There are three major sources of the to NO formed in the combustion: (1) the thermal $\mathrm{NO}$ (Zeldovich) mechanism, (2) the prompt $\mathrm{NO}$ (Fenimore) mechanism, (3) the $\mathrm{N}_{2} \mathrm{O} \rightarrow \mathrm{NO}$ intermediate route. The thermal mechanism is that the NO is formed by a set of highly temperature-dependent chemical reactions known as the extended Zeldovich mechanism. The principal reactions

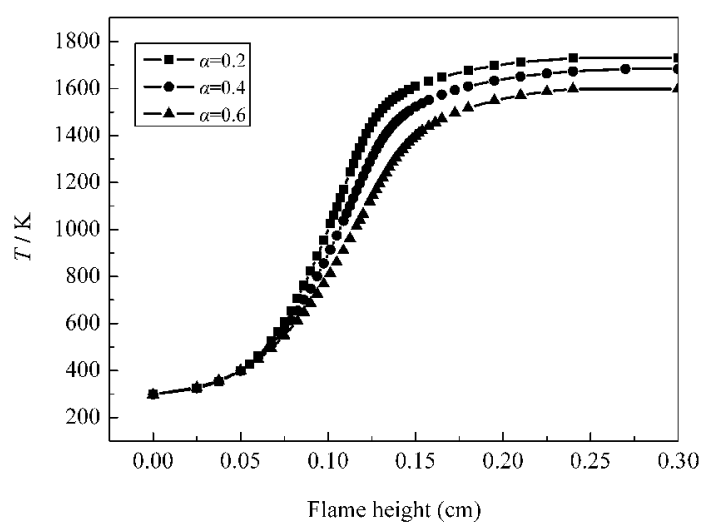

Fig.8 Profiles of temperature of $\mathrm{CH}_{4} /$ air flame with different $\mathrm{CO}$ additions at $\varphi=0.70$ 

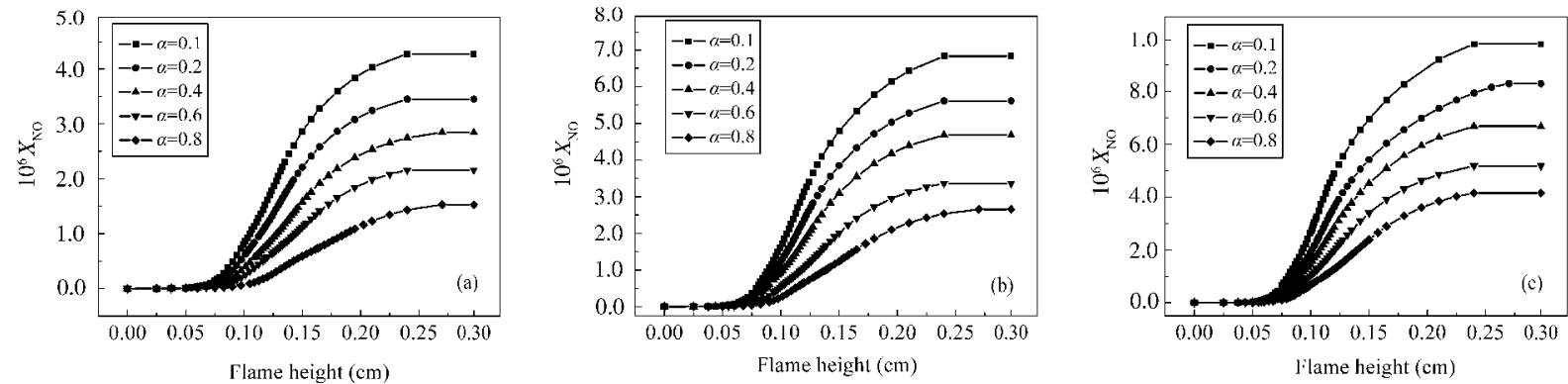

Fig.9 Profiles of NO mole fraction with different values of $\varphi$ $\varphi$ : (a) 0.70 , (b) 0.75 , (c) 0.80

governing the formation of thermal $\mathrm{NO}$ are as follows: $\mathrm{O}+\mathrm{N}_{2}=$ $\mathrm{NO}+\mathrm{N} ; \mathrm{N}+\mathrm{O}_{2}=\mathrm{O}+\mathrm{NO} ; \mathrm{N}+\mathrm{OH}=\mathrm{NO}+\mathrm{H} ; \mathrm{N}+\mathrm{NO}=\mathrm{O}+\mathrm{N}_{2}$. In the previous researches ${ }^{[29]}$, there were good evidences that prompt $\mathrm{NO}$ can be formed in a significant quantity in some combustion environments, such as in low-temperature, fuel-rich conditions. Although we study at the lean condition, to get precise analogue result, we also consider the prompt mechanism. This mechanism consists of the reactions ${ }^{[30]} ; \mathrm{CH}+\mathrm{N}_{2}=\mathrm{HCN}+\mathrm{N} ; \mathrm{HCN}+\mathrm{OH}=$ $\mathrm{CN}+\mathrm{H}_{2} \mathrm{O} ; \mathrm{CN}+\mathrm{O}_{2}=\mathrm{NO}+\mathrm{CO}$. The final mechanism involved main reaction: $\mathrm{N}_{2} \mathrm{O}+\mathrm{O}=2 \mathrm{NO}$. The main reaction ways of $\mathrm{NO}$ production and consumption can be obtained from Fig.10, which also shows the primary materials and radicals involved in the reactions clearly. According to information provided in Fig.10, and considering the reactions contained in GRI Mech 3.0, the main 28 steps reactions related NO have been listed in Table 1. Among them, R178, R179, R180 belong to the thermal mechanism, $\mathrm{R} 222$ belongs to the prompt route and $\mathrm{R} 182-\mathrm{R} 189$ are the $\mathrm{N}_{2} \mathrm{O} \rightarrow$ NO mechanism. We carry the NO concentration sensiti vity analysis on these 28 step reactions. Fig.11 shows (1) R178: N+ $\mathrm{NO}=\mathrm{N}_{2}+\mathrm{O}, \mathrm{R} 179: \mathrm{N}+\mathrm{O}_{2}=\mathrm{NO}+\mathrm{O}, \mathrm{R} 180: \mathrm{N}+\mathrm{OH}=\mathrm{NO}+\mathrm{H}, \mathrm{R} 189$ : $\mathrm{NO}_{2}+\mathrm{H}=\mathrm{NO}+\mathrm{OH}$, these four reactions play positive roles in the NO production which tallys with the mechanism, (2) R186: $\mathrm{HO}_{2}+$ $\mathrm{NO}=\mathrm{NO}_{2}+\mathrm{OH}$; $\mathrm{R} 249: \mathrm{CH}_{2}+\mathrm{NO}=\mathrm{H}+\mathrm{HNCO}$, are the main consumption routes. Fig.12 shows the profiles of the total production rates of NO. It can be observed that at $\varphi=0.70$, with the in-

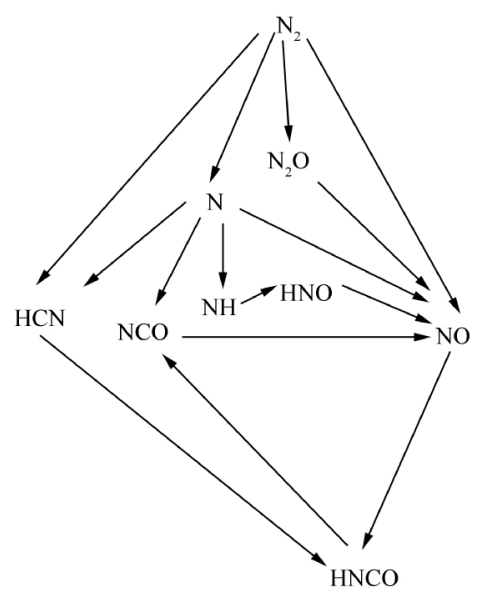

Fig.10 NO production and consumption ways in $\mathrm{CH}_{4} /$ air combustion crease of $\mathrm{CO}$ addition, the rate changes fluctuate severely much. With the three different $\mathrm{CO}$ additions, all the peak values appear at the flame height from 0.15 to 0.20 where the temperature rises to the maximum and the valley values appear at the height from 0.05 to 0.10 . Moreover, from the flame height 0.10 to 0.15 , the fluctuation is fierce and these regions are precisely the place in which the temperature rises quickest. From $\alpha=0.2$ to $\alpha=0.6$, the peak values reduce by $60 \%$, the valley values rise about $30 \%$.

Fig.13 indicated the profiles of NO production rate of the main

Table 1 Main reactions related to NO production and

\begin{tabular}{clcl}
\multicolumn{4}{c}{ consumption } \\
$\begin{array}{c}\text { Reaction } \\
\text { number }\end{array}$ & \multicolumn{1}{c}{ Reaction step } & $\begin{array}{c}\text { Reaction } \\
\text { number }\end{array}$ & \multicolumn{1}{c}{ Reaction step } \\
\hline $\mathrm{R} 178$ & $\mathrm{~N}+\mathrm{NO}=\mathrm{N}_{2}+\mathrm{O}$ & $\mathrm{R} 208$ & $\mathrm{NNH}+\mathrm{O}=\mathrm{NH}+\mathrm{NO}$ \\
$\mathrm{R} 179$ & $\mathrm{~N}+\mathrm{O}_{2}=\mathrm{NO}+\mathrm{O}$ & $\mathrm{R} 214$ & $\mathrm{HNO}+\mathrm{H}=\mathrm{H}_{2}+\mathrm{NO}$ \\
$\mathrm{R} 180$ & $\mathrm{~N}+\mathrm{OH}=\mathrm{NO}+\mathrm{H}$ & $\mathrm{R} 219$ & $\mathrm{CN}+\mathrm{H}_{2} \mathrm{O}=\mathrm{HCN}+\mathrm{OH}$ \\
$\mathrm{R} 182$ & $\mathrm{~N}_{2} \mathrm{O}+\mathrm{O}=2 \mathrm{NO}$ & $\mathrm{R} 222$ & $\mathrm{NCO}+\mathrm{O}=\mathrm{NO}+\mathrm{CO}$ \\
$\mathrm{R} 183$ & $\mathrm{~N}_{2} \mathrm{O}+\mathrm{H}=\mathrm{N}_{2}+\mathrm{OH}$ & $\mathrm{R} 240$ & $\mathrm{CH}+\mathrm{N}_{2}=\mathrm{HCN}+\mathrm{N}$ \\
$\mathrm{R} 185$ & $\left.\mathrm{~N}_{2} \mathrm{O}(+\mathrm{M})=\mathrm{N}_{2}+\mathrm{O}+\mathrm{M}\right)$ & $\mathrm{R} 246$ & $\mathrm{CH}+\mathrm{NO}=\mathrm{HCN}+\mathrm{O}$ \\
$\mathrm{R} 186$ & $\mathrm{HO}_{2}+\mathrm{NO}=\mathrm{NO} \mathrm{O}_{2}+\mathrm{OH}$ & $\mathrm{R} 247$ & $\mathrm{CH}+\mathrm{NO}=\mathrm{H}+\mathrm{NCO}$ \\
$\mathrm{R} 188$ & $\mathrm{NO}_{2}+\mathrm{O}=\mathrm{NO}+\mathrm{O}_{2}$ & $\mathrm{R} 248$ & $\mathrm{CH}+\mathrm{NO}=\mathrm{N}+\mathrm{HCO}$ \\
$\mathrm{R} 189$ & $\mathrm{NO}_{2}+\mathrm{H}=\mathrm{NO}+\mathrm{OH}$ & $\mathrm{R} 249$ & $\mathrm{CH}_{2}+\mathrm{NO}=\mathrm{H}+\mathrm{HNCO}$ \\
$\mathrm{R} 190$ & $\mathrm{NH}_{+}+\mathrm{O}=\mathrm{NO}+\mathrm{H}$ & $\mathrm{R} 250$ & $\mathrm{CH}_{2}+\mathrm{NO}=\mathrm{OH}+\mathrm{HCN}$ \\
$\mathrm{R} 192$ & $\mathrm{NH}+\mathrm{OH}=\mathrm{HNO}+\mathrm{H}$ & $\mathrm{R} 251$ & $\mathrm{CH}_{2}+\mathrm{NO}=\mathrm{H}+\mathrm{HCNO}$ \\
$\mathrm{R} 194$ & $\mathrm{NH}+\mathrm{O}_{2}=\mathrm{HNO}+\mathrm{O}$ & $\mathrm{R} 252$ & $\mathrm{CH}_{2}(\mathrm{~S})+\mathrm{NO}=\mathrm{H}+\mathrm{HNCO}$ \\
$\mathrm{R} 195$ & $\mathrm{NH}+\mathrm{O}_{2}=\mathrm{NO}+\mathrm{OH}$ & $\mathrm{R} 253$ & $\mathrm{CH}_{2}(\mathrm{~S})+\mathrm{NO}=\mathrm{OH}+\mathrm{HCN}$ \\
$\mathrm{R} 197$ & $\mathrm{NH}+\mathrm{H}_{2} \mathrm{O}=\mathrm{HNO}+\mathrm{H}_{2}$ & $\mathrm{R} 254$ & $\mathrm{CH}_{2}(\mathrm{~S})+\mathrm{NO}=\mathrm{H}+\mathrm{HCNO}$ \\
\hline \multicolumn{4}{c}{$\mathrm{CH}(\mathrm{S}):$ singlet state of methylene }
\end{tabular}

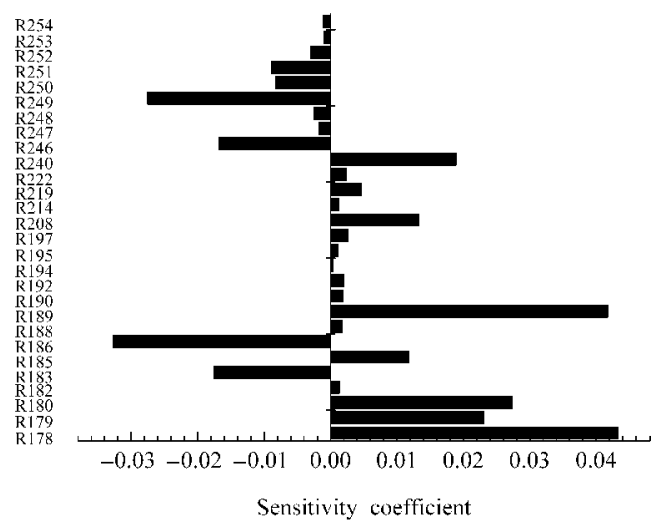

Fig.11 Sensitivity coefficients with respect to NO concentration 


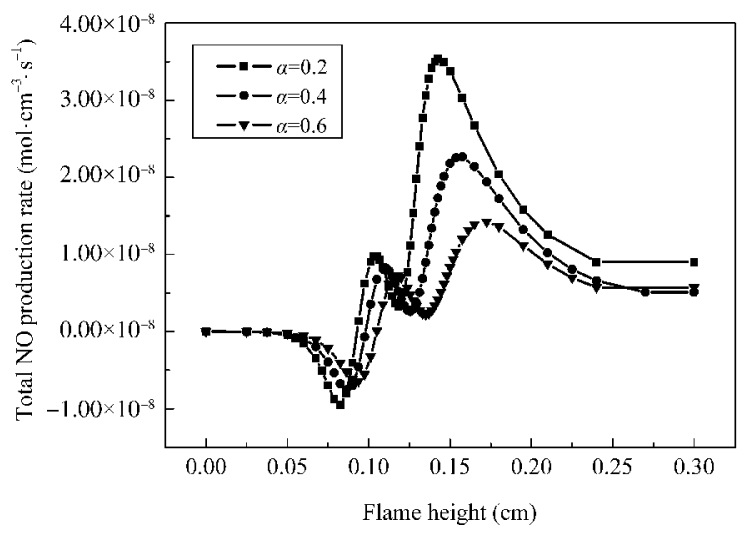

Fig.12 Profiles of total production rate of NO with different CO additions at $\boldsymbol{\varphi}=\mathbf{0 . 7 0}$

reactions (R178, R179, R180, R186, R189, R249) with different $\mathrm{CO}$ additions at $\varphi=0.70$. The results demonstrate that (1) as $\mathrm{CO}$ addition rises from 0.2 to 0.6 , the peak values of the four positive reactions reduce a lot, especially $\mathrm{R} 179\left(\mathrm{~N}+\mathrm{O}_{2}=\mathrm{NO}+\mathrm{O}\right)$, whose peak value changes from $9.0 \times 10^{-9}$ to $1.5 \times 10^{-9}$, about $80 \%$; (2) with an increase in the $\mathrm{CO}$ mole fraction, the valley values vary greatly at the flame height and the changes of R249 and R186 are remarkable; (3) the positions of the R179, R180, R189 peak
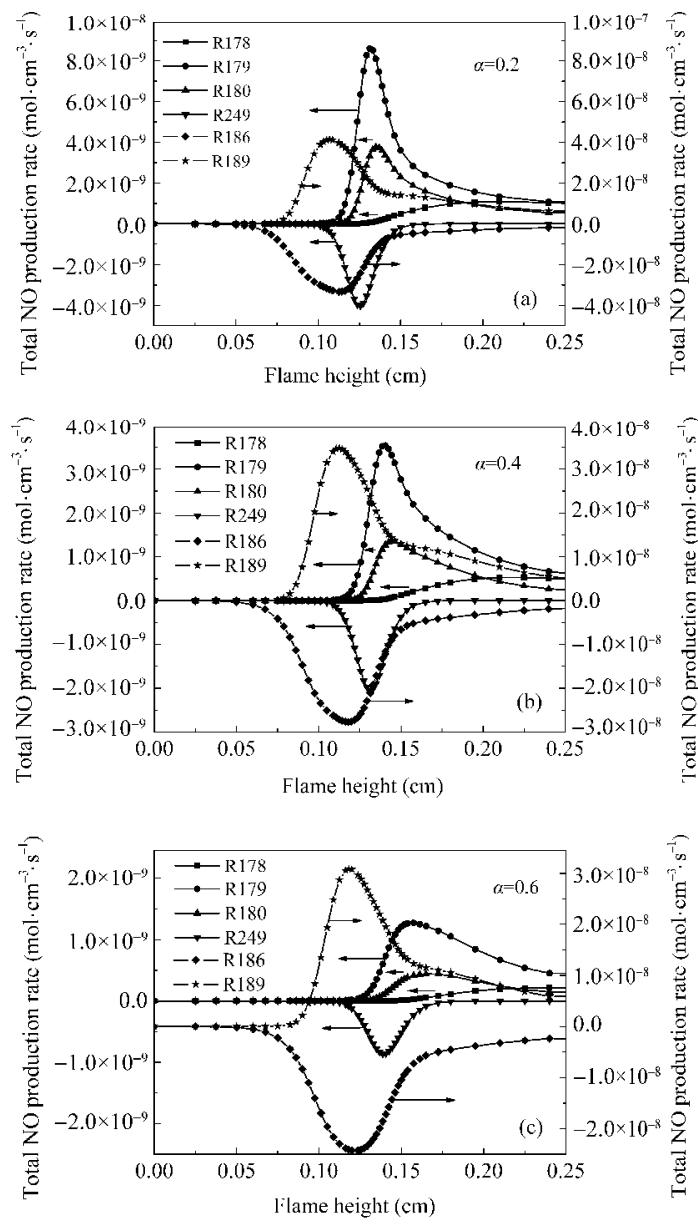

Fig.13 Profiles of NO production rate of the main reactions with various $C O$ additions at $\varphi=0.70$

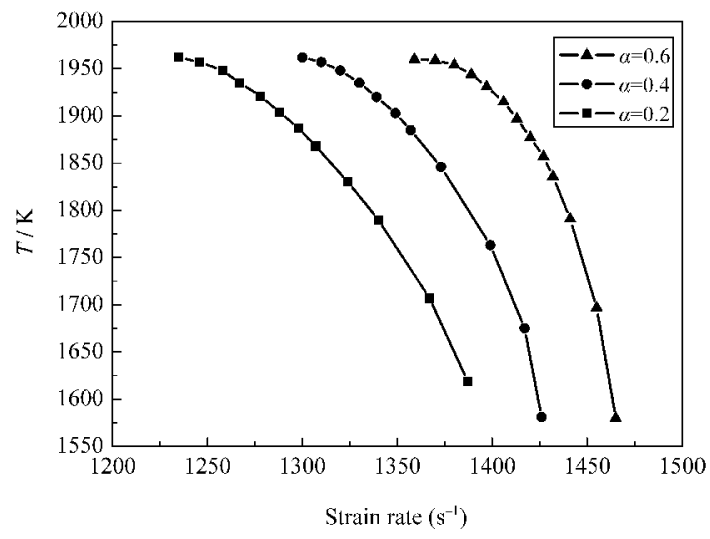

Fig.14 Temperature variation with strain rate with different $C O$ additions at $\boldsymbol{\varphi}=\mathbf{0 . 7 0}$

values are consistent with that of the total production rate peak value in Fig.12. But R178 is somewhat different, and the primary reason is that the temperature of $\mathrm{R} 178 \mathrm{~N}+\mathrm{NO}=\mathrm{N}_{2}+\mathrm{O}$ reaction must be higher than $1500 \mathrm{~K}$, which is in keeping with the temperature profiles in Fig.8.

\subsection{Extinction strain rate}

From the above analysis, the lean combustion can cause a decrease in the flame temperature and make the $\mathrm{NO}_{x}$ emissions under the effective control, but in the theory, the lean combustible gas has a weak stability, the flame stretch may possibly cause flameout. By CO addition, we hope that at low temperatures, it can maintain the high combustion intensity. Hence, it is important to investigate the changes of the strain rate and definite the extinction strain rate. Egolfopoulos et al. ${ }^{[3]]}$ studied the effects of the flame stretch experimentally and numerically. They focused on the flame structures and the extinction strain rates of the opposed jet and the single jet wall configuration. Ren et al. ${ }^{[5]}$ mainly aimed at the lean condition and got the extinction strain rate of the $\mathrm{CH}_{4} /$ air flame by using the opposed jet, symmetric, twinflame configuration. In this present study, we also adopt the opposed jet, symmetric, twin-flame configuration to get the effects of the strain rate on the $\mathrm{CO}$ enhanced lean $\mathrm{CH}_{4} /$ air flame. The preheat temperatures of the two nozzles are set to $400 \mathrm{~K}$ and the pressure is $1.0 \times 10^{5} \mathrm{~Pa}$. And in this section, we study the radial strain rate $S_{\text {rad }}$, which is defined as $S_{\text {rad }}=\frac{1}{r} \frac{\partial(v r)}{\partial r}$, where $r$ is the flame radius and $v$ is radial velocity. Fig. 14 demonstrates that at three test cases, as the strain rates increase, the flame temperatures decline monotonously. And when the flame temperature is below $1580 \mathrm{~K}$, the flame will become unstable, so the strain rate at $1580 \mathrm{~K}$ just is the extinction strain rate. From Fig.14, we can observe that, at the equivalence ratio $\varphi=0.70$, the extinction strain rate is $1387 \mathrm{~s}^{-1}(\alpha=0.2), 1426 \mathrm{~s}^{-1}(\alpha=0.4), 1465 \mathrm{~s}^{-1}(\alpha=0.6)$ respectively, i.e., with $\mathrm{CO}$ content increases, the extinction strain rate rises, which indicates that adding $\mathrm{CO}$ is able to strengthen the stability of the lean combustion.

\section{Conclusions}

Numerical computations of the effects of $\mathrm{CO}$ addition on the 
fundamental characteristics, such as the laminar burning velocity, the $\mathrm{NO}_{x}$ emissions, the extinction strain rate, are carried out with detailed chemistry and transport properties.

(1) The laminar burning velocity decreases with $\mathrm{CO}$ mole fraction from 0.2 to 0.7 in the lean conditions of $\varphi=0.65,0.70$, 0.75 . And the velocity depends on the peak value of $\mathrm{H}+\mathrm{OH}$ mole fraction, moreover more $\mathrm{CO}$ mole fraction in the fuel can cause the decrease of the maximum $\mathrm{OH}+\mathrm{H}$ mole fraction.

(2) Under lean condition, the flame temperature declined and the formation of $\mathrm{NO}$ is restrained much with $\mathrm{CO}$ addition, which can infer from the NO mole fraction profiles macroscopically and the production rate of the important reactions microscopicly. Besides, the important reactions about NO production got from sensitivity analysis can help obtain the effective methods to reduce $\mathrm{NO}_{x}$ emissions.

(3) With $\mathrm{CO}$ enrichment, the extinction strain rate is increased in a certain extent, that is, the $\mathrm{CO}$ addition can enhance the stability of the $\mathrm{CH}_{4} /$ air flame under the equivalence ratio $\varphi=$ 0.70 .

\section{References}

1 Law, C. K.; Wu, C. K.; Zhu, D. L.; Yu, G. Combustion and Flame, 1986, 63: 339

2 Frenklach, M.; Wang, H. Soot formation in combustion: mechanisms and models. Bockhorn, H. Ed. Berlin: SpringerVerlag, 1994, 59: 162-196

3 MacGregor, S. A.; Syred, N.; Claypole, T. C. Chemical Engineering Communications, 1987, 4-6: 163

4 Correa, S. Combustion Science and Technology, 1992, 87: 327

5 Ren, J. Y.; Egolfopoulos, F. N.; Tsotsis, T. T. Combustion Science and Technology, 2002, 174: 181

6 Ren, J. Y.; Egolfopoulos, F. N.; Tsotsis, T. T. Combustion and Flame, 2001, 124: 717

7 Zhang, Y. Y.; Wu, J. H. International Journal of Hydrogen Energy, 2009, 34: 519

8 Coppens, F. H. V.; De Ruyck, J.; Konnov, A. A. Combustion and Flame, 2007, 149: 409

9 Rørtveit, G. J.; Zepter, K.; Skreibergø, B.; Fossum, M.; Hustad, J. E. Proc. Combust. Inst., 2002, 29: 1123

10 Guo, H. S.; Neil, W. S. Combustion and Flame, 2009, 156: 477

11 Guo, H. S.; Smallwood, G. J.; Gülder, O. L. Proc. Combust. Inst., 2007, 31: 1197

12 Shy, S. S.; Chen, Y. C.; Yang, C. H.; Liu, C. C.; Huang, C. M. Combustion and Flame, 2008, 153: 510

13 Lee, C. E.; Lee, S. R.; Han, J. W.; Park, J. International Journal of Energy Research, 2001, 25: 343

14 Natarajan, J.; Lieuwen, T.; Seitzman, J. Laminar flame speeds and strain sensitivities of mixtures of $\mathrm{H}_{2}$ with $\mathrm{CO}, \mathrm{CO}_{2}$ and $\mathrm{N}_{2}$ at elevated temperatures. Proceedings of GT2007 ASME Turbo Expo 2007: Power for Land, Sea and Air. Montreal, Canada, GT200727967

15 Cho, E. S.; Chung, S. H. Journal of Mechanical Science and Technology, 2009, 23: 659

16 Frenklach, M.; Wang, H.; Goldenberg, M.; Smith, G. P.; Golden, D. M.; Bowman, C. T.; Hanson, R. K.; Gardiner, W. C.; Lissianski, V. GRI-Mech: an optimized detailed chemical reaction mechanism for methane combustion. Gras Research Institute, Tech. Rep. GRI951OO58. Chicago: Gras Research Institute, 1995

17 Guo, H.; Smallwood, G. J.; Liu, F.; Ju, Y.; Gülder, O. L. Proc. Combust. Inst., 2005, 30: 303

18 Kee, A. E.; Smoke, M. D.; Miler, J. A. PREMIX: a FORTRAN program for modeling steady laminar one-dimensional premixed flames. Albuquerque, NM/Livermore, CA: Sandia National Laboratories Report, 1985

19 Lutz, A. E.; Kee, R. J.; Grcar, J. F.; Rupley, F. M. OPPDIF: a FORTRAN program for computing opposed-flow diffusion flames. Albuquerque, NM/Livermore, CA: Sandia National Laboratories Report, 1997

20 Jiang, Y.; Qiu, R. Chinese Science Bulletin, 2005, 50(3): 276

21 Wu, C. Y.; Chao, Y. C.; Cheng, T. S.; Chen, C. P.; Ho, C. T. Combustion and Flame, 2009, 156: 362

22 Lutz, A. E.; Kee, R. J.; Miller, J. A. SENKIN: a FORTRAN program for predicting homogeneous gas phase chemical kinetics with sensitivity analysis. Albuquerque, NM/Livermore, CA: Sandia National Laboratories Report, 1987.

23 Kee, R. J.; Rupley, F. M.; Miller, J. A. Chemkin-II: a FORTRAN chemical kinetics. Albuquerque, NM/Livermore, CA: Sandia National Laboratories Report, 1989

24 Halter, F.; Chauveau, C.; Djebaïli-Chaumeix, N.; Gökalp, I. Proc. Combust. Inst., 2005, 30: 201

25 Hu, E. J.; Huang, Z. H.; He, J. J.; Miao, H. Y. International Journal of Hydrogen Energy, 2009, 34: 6951

26 Ren, J. Y.; Egolfopoulos, F. N.; Tsotsis, T. T. Industrial \& Engineering Chemistry Research, 2001, 40: 5155

27 Tuzson, J. Journal of Engineering for Gas Turbines and Power, 1992, 114: 682

28 Maughan, J. R.; Bowen, J. H.; Cooke, D. H.; Tuzson, J. Journal of Engineering for Gas Turbines and Power, 1996, 116: 78

29 Konnov, A. A. Combustion and Flame, 2009, 156: 2093

30 Vasudeevan, V.; Hanson, R. K.; Bowman, C. T.; Golden, D. M.; Davidson, D. F. J. Phys. Chem. A, 2007, 111: 11818

31 Egolfopoulos, F. N.; Zhang, H.; Zhang, Z. Combustion and Flame, 1997, 109: 237 